\title{
THE EFFECT OF CORPORATE SOCIAL RESPONSIBILITY (CSR) DISCLOSURE ON TAX AVOIDANCE WITH GENDER AS MODERATING VARIABLE IN MINING COMPANIES
}

\author{
Friska Luxmawati ${ }^{1}$ \\ Febrina Nafasati $\mathrm{P}^{2}$
}

Faculty of Economics, Universitas Semarang

\begin{abstract}
This study aims to determine the effect of Corporate Social Responsibility (CSR) disclosure on tax avoidance in Indonesia and also to determine the relationship between Corporate Social Responsibility (CSR) disclosure on tax avoidance with gender as the moderating variable. This study was conducted in 19 mining companies listed on the Indonesia Stock Exchange (IDX) during the 2016-2017 period using secondary data. Samples were selected using purposive sampling method with the total of 38 observations. Data analysis in this study uses simple regression analysis and Moderated Regression Analysis (MRA) with independent variable of Corporate Social Responsibility (CSR), dependent variable of tax avoidance, and moderating variable of gender. The results showed that Corporate Social Responsibility (CSR) had no effect on tax avoidance. Gender is able to moderate the effect of Corporate Social Responsibility (CSR) on tax avoidance
\end{abstract}

Keywords: Corporate Social Responsibility (CSR), Tax Avoidance, Gender

$\underline{1}$ luxmawati_friska@yahoo.co.id; Faculty of Economics, Universitas Semarang
${ }^{2}$ febrina@usm.ac.id; Faculty of Economics, Universitas Semarang 


\section{INTRODUCTION}

Tax is the mandatory contribution to the State owed by individuals or entities that are coercive based on the law, with no direct compensation and is used for state needs for the greatest prosperity of the people (Article 1 of the Republic of Indonesia Law No. 28/2007 concerning Third Amendment to Law Number 6 Year 1983). Tax is an important phenomenon that is always experiencing development, therefore tax must be managed properly. In order to increase state revenue from the tax sector, the public is placed in the leading position in the implementation of their tax obligations. This is very much in line with social-oriented demands, where the people determine their lives and activities the most, while the government functions more as the supervisor, the guide and the provider of facilities (Hanum, 2013).

However, in the implementation the tax payers and the government have different interests related to tax payments. Taxpayers tend to reduce the amount of tax payments, while the government is trying to increase tax revenue. For the taxpayers, especially companies or business entities, tax is one of the main burdens that will reduce their net income. While from the government side, the increase in tax revenue as the source of state finance is as the source of funds intended to finance government expenditures (Waluyo in Sugitha \& Supadmi, 2016). So, both directly and indirectly it will affect the policies taken by the company management, for examples the decisions on expansion, investment, and other transactions that also affect the tax burden of the company (Lestari in Amri, 2017). This taxpayer action is called tax avoidance.

In general, tax avoidance is considered legal because it utilizes more loopholes (slit and opportunities of tax saving) that exist in applicable tax regulations. According to Law Number 17 Year 2000, loopholes in taxation are the condition, the regulation, the transaction or the event that allows a person or business entity to get the opportunity to save on tax payments or avoid certain tax obligations or avoid the imposition of tax administrative sanctions.

One of the factors that the companies can do to avoid taxes is by disclosing Corporate Social Responsibility (CSR). According to the Government Regulation Number 47 Year 2012 which states that the realization of the budget for the implementation of social and environmental responsibility carried out by the Company is calculated as Company expense. Corporate Social Responsibility (CSR) according to the 
World Bank Group is referred to as the sustainable business commitment that contributes to the economy and influences the surrounding environment and the general public to improve the quality of facilities and the community survival. From the definition, it is mentioned that tax and Corporate Social Responsibility (CSR) are both intended for general welfare. But the difference is that taxes are managed by the central and regional governments which are then distributed to the general public while the cost of implementing Corporate Social Responsibility (CSR) is managed by the company and then distributed to the general public (Hidayati \& Fidiana, 2017).

Corporate Social Responsibility (CSR) is one of the business decisions taken by parties within the company. The selection and the determination of a business decision also requires adequate human resources from the decision makers, in this case the board of commissioners and the directors who are the company's organs. The board of commissioners and the directors can be women and men or commonly referred to as gender. The existence of women in the company is expected to provide equal opportunities for everyone and give the right decision with the lower risk (Kusumastuti, et al in Amri, 2017).

Women tend to have a high degree of caution, conscientious, and avoid risk. The companies that have a diversified gender composition or at least have one female director will increasingly make efficiency through tax avoidance action. In accordance with the proposition submitted by Robinson and Dechant (in Amri, 2017) the companies that have diversified directors' characteristics are considered to have good skills related to operations and other policies that also affect the amount of tax payments paid by the company.

According to the recognition from the Directorate General of Taxes, there are inequalities in taxation data on the mineral and coal mining sector. The contribution of the mineral and coal sector to tax revenue also shows declining trend throughout 20122016, from 5 percent to 2 percent, from Rp 28 trillion in 2012 to only Rp 16 trillion in 2016. The tax ratio in the mineral and coal mining sector also show a decline throughout 2011-2016, which is 12 percent to 3.88 percent. So that tax revenue in the mining sector is cause for concern. Then in 2017, tax payments from the mining sector grew 28 percent from the previous period. This was caused by the increase in mining commodity prices since last year which succeeded in increasing the profitability of the business so that it 
affects the tax payment. Besides that mining companies are the business sectors that have the highest risk among other sectors, namely manufacturing, banking, property and real estate sectors. The impact of mining activities on the environment and surrounding communities is very high, because it threatens the preservation of the livong environmental functions. The higher the risk of the company, the higher the tax avoidance action. High company risk causes the cost of Corporate Social Responsibility $(C S R)$ incurred is also high. Corporate Social Responsibility $(C S R)$ is a form of corporate strategy to do tax avoidance.

\section{THEORETICAL BACKGROUND}

\section{A. The Effect of Corporate Social Responsibility (CSR) on Tax Avoidance}

The disclosure of Corporate Social Responsibility (CSR) is part of the accounting for social responsibility to stakeholders. The companies that have implemented Corporate Social Responsibility (CSR) practices can disclose the implementation of the Corporate Social Responsibility (CSR) either integrated directly in annual reports or separate reports which are often referred to as sustainability reports (Annisa \& Nazar, 2015).

Corporate Social Responsibility (CSR) as a strategy to avoid taxes, get the political access for business interests, and attract public sympathy. The company reports the Corporate Social Responsibility (CSR) activities with smaller value of funds by creating fake Corporate Social Responsibility (CSR) programs and activities and marking up CSR costs in large amount of number (Lako, 2016). Seen from the perspective of Income Tax $(\mathrm{PPh})$, the companies will usually choose the strategy to anticipate the imposition of this tax so that all costs incurred for Corporate Social Responsibility (CSR) activities carried out can be charged as costs that reduce taxable profits (Maesarah, et al., 2014).

The higher the level of Corporate Social Responsibility (CSR) disclosure performed by the companies, the lower the tax avoidance done by the companies. That is because a company that discloses Corporate Social Responsibility (CSR) but does tax avoidance, will affect the company's reputation so that the community or stakeholder assessment decreases. Therefore the companies that have disclosed Corporate Social Responsibility (CSR) are expected to avoid tax avoidance practices (Saputro, 2016).

In Sari and Adiwibowo's research (2017), they convinced that Corporate Social 
Responsibility (CSR) is stated because of corporate culture, the companies that are more responsible are implicitly less likely to perform tax avoidance. This shows that the higher the level of Corporate Social Responsibility (CSR) disclosed by a company will reduce the practice of tax avoidance (Dharma \& Noviari, 2017). So the hypothesis developed in this study is:

\section{H1: The Disclosure of Corporate Social Responsibility (CSR) affects tax avoidance.}

\section{B. The Effect of Corporate Social Responsibility (CSR) on Tax Avoidance with Gender as the Moderating Variable}

Gender is the difference between men and women in roles, functions, rights, responsibilities, and behaviors that are formed by social, cultural and custom values of community groups that can change according to the local time and conditions (Puspitawati in IPB, 2011). Decision making is the key to life and activities the most of all activities in dealing with various problems to be able to sustain life (Wulansari, 2011). According to Friedman and Schustack (2009) the characteristics of men and women influence the decision making of the board of commissioners and the directors.

When in a company's decision making is the board of commissioners and directors of men where men have courageous nature, strong reasoning, active and tend to be brave to take risks, the companies that have male commissioners and directors are bolder in making decisions regarding the disclosure of Corporate Social Responsibility (CSR), then the disclosure of Corporate Social Responsibility (CSR) will be lower, so the practice of tax avoidance will be higher.

When in the company decision making there are women boards of commissioners and directors where women have weak-emotional personality, unprincipled, easily influenced, difficult to overcome problems and easily submit (submissive), the companies that have female boards of commissioners and directors are more afraid in making decisions about the disclosure of Corporate Social Responsibility (CSR), then the disclosure of Corporate Social Responsibility (CSR) carried out will be higher so that the practice of tax avoidance carried out will be lower.

In Ningrum, et al study (2018) the companies that perform extensive disclosure of Corporate Social Responsibility (CSR) do not practice tax avoidance. The presence of 
women on the board of commissioners and directors (gender) can strengthen the effect of Corporate Social Responsibility (CSR) on tax avoidance. So the presence of women on company boards can not contribute to making the right decision to perform extensive disclosure and tax avoidance practices. So the hypothesis developed in this study is:

H2: Gender moderates the effect of Corporate Social Responsibility (CSR) on tax avoidance

\section{METHOD, DATA AND ANALYSIS}

The research variable in this study consist of the Independent Variable namely Corporate Social Responsibility (CSR). Corporate Social Responsibility (CSR) in this study was calculated based on GRI G4 indicators. In GRI G4 standard (2013) the performance indicators are divided into 3 (three) main components, namely economic (9 items), environment (34 items), and social including labor practices and work comfort (16 items), human rights (12 items ), community (11 items), product responsibility ( 9 items) with the total performance indicator reaching 91 indicators (Putri, 2017). This measurement is carried out by matching the items on the check list with items disclosed by the company. If item $y$ is disclosed then it is given a value of 1 , if item $y$ is not disclosed then it is given a value of 0 in the check list. After identifying the items disclosed by the company in the annual report, as well as matching them to the check list, the results of the disclosure of items obtained from each company are indexed with the CSRDi proxy. Then, the total value of disclosure is used to measure the Corporate Social Responsibility (CSR) index (Putri, 2017).

The dependent variable that is tax avoidance in this study is proxied using the Effective Tax Rates (ETR) ratio. According to Muzzaki and Darsono (2015) the companies that have ETR value (close to 0) are considered to be higher in tax avoidance, while the higher the value of ETR (near 1), the companies are considered to be lower in the level of tax avoidance. The low ETR is also a sign of corporate tax avoidance activity.

The next variable in this study is the moderating variable, namely Gender. In this study gender that is the proportion of women on the board of commissioners and directors is compared to the total number of the members of the board of commissioners and directors (Ningrum, et al., 2018). 
The population in this study are mining companies listed on the Indonesia Stock Exchange (IDX) for the 2016-2017 period. To test the hypothesis in this study, samples were selected based on the following criteria (1) the mining companies listed on the Indonesia Stock Exchange in the 2016-2017 period, (2) the companies that publish annual reports and disclose their Corporate Social Responsibility (CSR) activities in annual reports during the study period, (3) the companies that do not experience losses, because the companies that experience losses will produce the distorted effective tariff.

The analyses of the data used in this research are descriptive statistical analysis; classic assumption test; simple linear regression, Moderated Regression Analysis (MRA); significance test of individual or partial parameters ( $\mathrm{t}$ test); simultaneous significance test (f test); and the coefficient of determination $\left(\mathrm{R}^{2}\right)$.

\section{RESULTS AND DISCUSSION}

The number of mining companies listed on the Indonesia Stock Exchange (IDX) and issuing Corporate Social Responsibility (CSR) disclosures for 2 (two) years, namely from 2016 to 2017 is 19 companies, bringing the total research samples to 38 samples. Of the 38 samples, 4 samples were outsourced to meet the classic assumption test of normality. So that the total samples used in this study were 34 samples.

The test results for Model 1 or the first Hypothesis show the results of partial test $(\mathrm{t}$ test) that the Corporate Social Responsibility (CSR) variable obtains t-value of -1.312 with the significance value of 0.199 , greater than 0.05 , then the hypothesis 1 is rejected. This proves that Corporate Social Responsibility (CSR) has no effect on tax avoidance. Corporate Social Responsibility (CSR) is a form of corporate social responsibility to the community where the companies operating in the community can disrupt the community activities and the surrounding environment. Therefore, the Corporate Social Responsibility (CSR) carried out by the companies is an obligation that must be fulfilled by the companies without involving tax avoidance. This is because since the enactment of Law No. 40 Year 2007 which regulates the company's obligations to disclose Corporate Social Responsibility (CSR). So Corporate Social Responsibility (CSR) is an obligation that must be done by the companies that have beem go public. Due to being an obligation, the implementation of Corporate Social Responsibility (CSR) of a company is no longer concerned about tax avoidance actions. The results of this study are in line with the 
research conducted by Reinaldo (2017) and not in line with the research conducted by Sari \& Adiwibowo (2017) and Dharma \& Noviari (2017) which state that Corporate Social Responsibility (CSR) affects tax avoidance.

The test results for model 2 or the second hypothesis using the Moderated Regression Analysis (MRA) analysis tool show that the $\mathrm{t}$ value of -2.838 with a significance of 0.008 is smaller than 0.05 . So it can be concluded that gender is a moderating variable of Corporate Social Responsibility (CSR) to the tax avoidance variable, because the results of the moderating test found negative and significant effect results. From the interaction of Corporate Social Responsibility (CSR) and gender as the moderating variables, it is found that the value of $t$ is 2.605 with the significance of 0.014 less than 0.05 , then hypothesis 2 is accepted. The samples in this study amounted to 34 companies. The calculation of the percentage of the board of commissioners and directors of women and men is known by the number of boards of commissioners and directors of men in the company board of 155 people or as much as 91.7 percent. Then there are 14 women or 8.3 percent. From the data it is known that the Board of Commissioners and directors of men are more than women. So that when making decisions in the company, it is done more by the male board of commissioners and directors. According to Friedman and Schustack (2008) the advantage of male gender is someone who tends to be brave in taking responsibility in small groups, men have strong and rational reasoning and are superior in arithmetic and spatial fields so that they have better thinking. In addition, men are able to take decisions and do not depend on others, assertive and tend to use more logic in making a decision, so it is easier to distinguish between taste and ratio. Here it can be said that men have the courageous nature, strong reasoning, active and tend to be more willing to take risks so that the companies that have the male board of commissioners and directors are more willing to take risks in terms of decisions regarding the disclosure of Corporate Social Responsibility (CSR). So that the disclosure of Corporate Social Responsibility (CSR) made by the company will be even lower, where CSR disclosure only meets the obligations required by the company law. This has resulted in the higher tax avoidance practices carried out by companies.

Conversely, according to Friedman and Schustack (2008) woman has the advantages as someone who has nurturing, gentle and peace-loving, communicative and sociable character. The advantages possessed by the women are the traits that are not 
related to decision making. The weakness of women according to Fredman and Schustack (2008) is someone who has a weak-emotional personality, unprincipled, easily influenced, difficult to overcome problems and easily surrender (submissive) so that the companies that have the board of commissioners and directors of women are more afraid to take risks. So as an effort to reduce the amount of tax that must be paid, women will perform high Corporate Social Responsibility (CSR) disclosure. This causes the practice of tax avoidance to be carried out will be increasingly low. The results of this study are in line with the research conducted by Ningrum, et al (2018) which states that gender moderates the relationship between Corporate Social Responsibility (CSR) and tax avoidance.

\section{CONCLUSIONS}

Based on the results of this study, it can generally be concluded that Corporate Social Responsibility (CSR) measured using the GRI-G4 disclosure index has no effect on tax avoidance. This shows that Corporate Social Responsibility (CSR) is the company's obligation without involving tax avoidance. Gender is able to moderate the effect of Corporate Social Responsibility (CSR) on tax avoidance. There are differences between women and men in the decision making related to the implementation of Corporate Social Responsibility (CSR).

In accordance with the results of the research related to the disclosure of Corporate Social Responsibility (CSR), the companies are expected to comply with the regulations made by the government regarding the company's obligations to disclose the social responsibility to the public properly. In addition the company can also plan taxes in accordance with statutory regulations by not overusing.

Although this study has tried its best to see what factors influence the disclosure of Corporate Social Responsibility (CSR), but this study still has limitations, including the following:

1. R2 value of 0.253 means that 25.3 percent of the tax avoidance dependent variable can be influenced by the independent variable of Corporate Social Responsibility (CSR) and gender, while 74.7 percent can be influenced by other variables. 
2. This study has the potential for subjectivity when the researcher conducts the check list of Corporate Social Responsibility (CSR) disclosure using the GRI-G4 index and GRI-G4 items which are expressed in unclear indicators.

Based on the limitations obtained by the researcher during the study, then for the future research, it is expected to:

1. Add other variables that can affect the disclosure of Corporate Social Responsibility (CSR).

2. Conduct the check list by having groups of at least three people, in order to minimize the subjectivity of the researcher and then clarify the GRI-G4 items disclosed on the indicators.

\section{REFERENCES}

Amri, M. (2017). Pengaruh Kompensasi Manajemen Terhadap Penghindaran Pajak Dengan Moderasi Diversifikasi Gender Direksi dan Preferensi Risiko Eksekutif Perusahaan di Indonesia. Jurnal Aset (Akuntansi Riset), Vol. 9, No. 1, hlm. 1-14

Annisa, N., \& Nazar, M. R. (2015). Pengaruh Profitabilitas, Umur, dan Ukuran Perusahaan Terhadap Corporate Social Responsibility. Proceeding of Management, Vol. 2, No. 1, hlm. 313

Budiman, J., \& Setiyono. (2012). Pengaruh Karakter Eksekutif Terhadap Penghindaran Pajak (Tax Avoidance). Proceeding Simposium Nasional Akuntansi 15

Bursa Efek Indonesia. (2017). Laporan Keuangan dan Tahunan Perusahaan Tercatat (online), (http://www.idx.co.id/, diakses 23 Juli 2018).

Dharma, N. B. S., \& Noviari, N. (2017). Pengaruh Corporate Social Responsibility dan Capital Intensity Terhadap Tax Avoidance. E-Jurnal Akuntansi Universitas Udayana, Vol. 18, No. 1, hlm. 529-556

Fatimah, Anwar, K., Nordiansyah, M., \& Tambun, S. P. (2017). Pengaruh Intensitas Modal, Kompensasi Eksekutif, dan Kualitas Audit Terhadap Tindakan Penghindaran Pajak Pada Perusahaan Manufaktur yang Terdaftar di Bursa Efek Indonesia. Prosiding ABIS

Friedman, H. S., \& Schustack, M. W. (2009). Kepribadian Teori Klasik dan Riset Modern. Edisi Ketiga. Jilid 2. Jakarta: Erlangga Ghozali, I. (2013). Aplikasi Analisis Multivariate dengan Program IBM SPSS 21. Edisi Tujuh. Semarang: Universitas Diponegoro

Global Reporting Initiative. (2018). Sustainability Reporting Guidelines G4, (http://www.globalreporting.org/, diakses 10 September 2018).

Hanum, H. R. \& Zulaikha. (2013). Pengaruh Karakteristik Corporate Governance Terhadap Effective Tax Rate (ETR). Diponegoro Journal of Accounting, Vol. 2, No. 2

Hidayati, N., \& Fidiana. (2017). Pengaruh Corporate Social Responsibility dan Good Corporate Governance Terhadap Penghindaran Pajak. Jurnal Ilmu dan Riset Akuntansi, Vol. 6, No. 3 
Indriantoro, N., \& Supomo, B. (2016). Metodologi Penelitian Bisnis. Edisi Pertama. Yogyakarta: BPFE

Kementrian Keuangan Republik Indonesia. (2017). Berita Pajak dan Realisasi Pajak, (http://www.kemenkeu.go.id/, diakses 26 Juli 2018).

Lako, A. (2016). Hukum Tabur-Tuai CSR, (http://news.unika.ac.id/, diakses 10 September 2018).

Maesarah, Yati, dkk. (2014). Pengaruh Karakteristik Perusahaan dan Corporate Social Responsibility Terhadap Penghindaran Pajak. Simposium Nasional Akuntansi 17

Maharani, I. G. A. C., \& Suardana, K. A. (2014). "Pengaruh Corporate Governance, Profitabilitas, dan Karakteristik Eksekutif Pada Tax Avoidance Perusahaan Manufaktur". E-Jurnal Akuntansi Universitas Udayana, Vol. 9, No. 2, hlm. 525539

Majalah CSR. (2017). Peluncuran GRI Standards 2018 : Membaca Arah Akuntabilitas Masa Depan, (http://majalahcsr.id/, diakses 10 September 2018).

Mursitama, T. N., Hasan, M. F., \& Fakhrudin, I. Y. (2011). Corporate Social Responsibility (CSR) di Indonesia : Teori dan Implementasi : Studi Kasus Community Development Riaupulp. Institute for Development of Economics and Finance.

Muzakki, M. R., dan Darsono. (2015). Pengaruh Corporate Social Responsibility dan Capital Intensity Terhadap Penghindaran Pajak. Diponegoro Journal of Accounting, Vol. 4, No. 3

Ningrum, A. K., Suprapti, E., \& Anwar. A. S. H. (2018). Pengaruh Pengungkapan Corporate Social Responsibility Terhadap Tax Avoidance Dengan Gender Sebagai Variabel Moderasi. Jurnal Balance, Vol. 15, No. 1

Puspawati, D., Praswati, A. N., \& Abas, N. I. (2018). Penghindaran Pajak dan Corporate Social Responsibility: Kinerja Laba Sebagai Variabel Moderasi. STIKES PKU Muhammadiyah Surakarta

Putri, F. N. (2017). Pengaruh Corporate Social Responsibility dan Capital Intensity Terhadap Tax Avoidance. Fakultas Ekonomi dan Bisnis, Universitas Lampung. Bandar Lampung

Radyati, M. R. N. (2014). Sustainable Business dan Corporate Social Responsibility (CSR). First Edition. Jakarta: Universitas Trisakti

Rahayu, R. N. (2016). Pengaruh Struktur Kepemilikan Asing, Kepemilikan Institusional, dan Kepemilikan Manajerial Terhadap Luas Pengungkapan Corporate Social Responsibility (CSR),(http://repository.widyatama.ac.id)

Reinaldo, R. (2017). Pengaruh Leverage, Ukuran Perusahaan, ROA, Kepemilikan Institusional, Kompensasi Kerugian Fiskal, dan CSR Terhadap Tax Avoidance. JOM Fekon, Vol. 4, No. 1

Resmi, S. (2013). Perpajakan Teori dan Kasus. Edisi Tujuh. Jakarta: Salemba Empat

Rezika, M. B. (2017). Pengaruh Mekanisme Corporate Governance dan Profitabilitas Terhadap Tax Avoidance. Fakultas Ekonomi dan Bisnis, Universitas Pasudan. Bandung.

Rikysanria. (2016). Pengertian, Fungsi, Aplikasi dan Contoh dari CSR (Corporate Social Responsibility), (http://rikysanria.blogspot.com/, diakses 08 September 2018).

SahamOK. (2017). Emiten Sektor Pertambangan, (http://www.sahamok.com/, diakses 23 Juli 2018). 
Saputro, T. S. (2016). Pengaruh Kualitas Audit dan Corporate Social Responsibility Terhadap Tax Avoidance. Fakultas Ekonomi dan Bisnis, Universitas Negeri Islam Syarif Hidayatullah. Jakarta

Sari, L. L. P., \& Adiwibowo, A. S. (2017). Pengaruh Corporate Social Responsibility Terhadap Penghindaran Pajak Perusahaan. Diponegoro Journal Of Accounting, Vol. 6, No. 4, hlm. 1-13

Subakti, T. A. V. (2012). Pengaruh Karakteristik Perusahaan dan Reformasi Perpajakan Terhadap Penghindaran Pajak di Perusahaan Industri Manufaktur yang Terdaftar di Bursa Efek Indonesia Tahun 2008-2010.

Jurnal Ekonomi dan Bisnis Universitas Tri Sakti Sudarma, M. (2008). Sosiologi Untuk Kesehatan. Jakarta: Salemba Medika

Sugitha, I. M. Y. P., \& Supadmi, N. L. (2016). Pengaruh Karakteristik Perusahaan dan Beban Iklan Pada Tindakan Penghindaran Pajak. E-Jurnal Akuntansi Universitas Udayana, Vol. 17, No. 2, hlm. 1311-1341

Sugiyono. (2011). Metode Penelitian Kuantitatif, Kualitatif dan R\&D. Bandung: CV. Alfabeta

Sukmawaty, S. (2017). Membangun Daerah Melalui Kebijakan Tanggung Jawab Sosial Perusahaan. Jurnal Selat, Vol. 4, No. 2, hlm. 205-218

Undang-Undang Republik Indonesia, Nomor 17 Tahun 2000, Perubahan Ketiga Atas Undang-Undang Nomor 7 Tahun 1983 tentang Pajak Penghasilan

Undang-Undang Republik Indonesia, Nomor 28 Tahun 2007, Perubahan Ketiga Atas Undang-Undang Nomor 6 Tahun 1983 tentang Ketentuan Umum dan Tata Cara Perpajakan

Undang-Undang Republik Indonesia, Nomor 40 Tahun 2007 tentang Perseroan Terbatas

Wulansari, D. A. (2011). Perbedaan Pengambilan Keputusan Antara Remaja Putra Dengan Remaja Putri. Universitas Muhammadiyah Surakarta

Yoehana, M. (2013). Analisis Pengaruh Corporate Social Responsibility Terhadap Agresivitas Pajak. Fakultas Ekonomika dan Bisnis, Universitas Diponegoro. Semarang 